\title{
The Missing God Telipinu Myth: A Chapter from the Ancient Anatolian Mythology
}

\author{
Kayıp Tanrı Telipinu Mitosu: \\ Eskiçăg Anadolu Mitolojisinden Bir Kesit
}

\begin{abstract}
"The God Telipinu was held an angry attack ... He (hastily) put on his right shoe to his left foot, and his left one to the right. (And he left his country. With his departure) the fog kept (filled) the windows, the smoke kept (filled) the house; the woods in the oven were smothered; the gods of horses were smothered; the sheep in the fold were smothered, the cattle in the stable were smothered; the sheep refused her lamb; the cow refused her calf. Telipinu went away; he turned the fertility of animals and seeds, their productivity and (also) their abundance to desert end meadow."

“Tanrı Telipinu öfke nöbetine tutulmuştur... O, (aceleyle) sağ ayakkabısını sol ayağına ve sol ayakkabısını sağ ayağına giydi. (ve ülkesini terk etti, onun gidişiyle) pencereleri sis tuttu (doldurdu), evi duman tuttu (doldurdu), ocaktaki odunlar boğuldu, altardaki tanrılar boğuldu, ağıldaki koyunlar boğuldu, ahırdaki sığırlar boğuldu, koyun kuzusunu reddetti, inek buzağısını reddetti, Telipinu çekip gitti, tohumların ve hayvanların doğurganlığını, bereketliliğini, gelişmesini, bereketliliğini ve bolluğunu (da) bozkıra ve çayıra döndürdü”
\end{abstract}

Esma Reyhan*

\begin{abstract}
The Hittites haven't their own mythos. They served as a bridge to transfer this kind of literary creations from the local Anatolians (Hatti) and the other cultures (Hurri and Mesopotamia) to the ancient civilizations. The most important one of those samples is the mythos, called as "The missing God Telipinu", which build on
\end{abstract}


a theme about "turning back a god who got angry to someone or something, and went away the country, so with his departure, he took away the wealth and abundance".

Key Words: Myth, God Telipinu, Kizzuwatna, Goddess Kamrušepa, Analogy

$\ddot{O} z$

Hititlerin kendilerine özgü mitosları yoktu. Onlar, yerli Anadolu (Hatti) ve diğer kültü̈lerden (Hurri, Mezopotamya) aldıları bu türdeki edebi ürünlerin, Antik Dönem uygarlıklarına aktarılmasında bir köprü vazifesi gördüler. Bunun en güzel örneği, "her hangi bir kimseye ya da olaya öfkelenerek ülkeyi terk edip giden ve gidişiyle bolluk ve bereketi de beraberinde götüren tanrıyı geri döndürme" konusu üzerine kurulan Hatti kökenli "Kayıp Tanrı Telipinu” mitosudur.

Anahtar Kelimeler: Mitos, Tanrı Telipinu, Kizzuwatna, Tanrıça Kamrušepa, Analoji.

The ancient societies believed that an angry god might cause to the negative natural events such as storm, drought, flood etc. Therefore various gods, who were kept responsible for the natural events, came out in the prehistoric period. For instance, Telipinu, the son of Storm God, is an agricultural god. ${ }^{1}$ The agricultural activities such as sowing, plowing and irrigating, etc, are under his responsibility. Naturally, the disappearing of this god affected the nature and also, indirectly, the entire life. In many ancient societies, the missing god myths represent the transitions of seasons and the changes which were observed in the nature.

Telipinu Myth appears in different forms in the prehistoric period, such as Dumuzi/Tammuz and Inanna/Ištar ${ }^{2}$ in Mesopotamia, Demeter and Persephone ${ }^{3}$ in ancient Greece or Baal ${ }^{4}$ myth in Syria. In those creations, it

* Assist. Prof. Dr., Faculty of Science and Letters, Department of History.

${ }^{1}$ M.A.Dinçol, 1982: 100

${ }^{2}$ Dumuzi, Sumerian Tammuz; Sumerian Inanna is identical with Semitic Inanna. In the mythos, it mentioned about the chaos in the land which came out, when god Telipinu went down to the world of deaths, the efforts of Inanna/Ištar who desires to solve this problem and turning Tammuz back to the world of deaths, after many endeavors. (S. H. Hooke, Ortadoğu Mitolojisi, (Trans.A. Șenel), Ankara 1991).

${ }^{3}$ Hades, the daughter of Zeus and Demeter, kidnaps Persephone to the world of deaths to make her his everlasting wife. Demeter asks for the intervention of Zeus to save her daughter from Hades. Hades gives a pomegranate to Persephone before he sends out her. And she eats a piece of pomegranate. By tasting a food in the world of deaths, she unconsciously promises to come back to there again. Consequently, she would remain near her mother in two out of three of a year; the remaining time of a year time, she would spend in the Underground world. This period is equal to the winter time. Demeter decorates the earth with flowers and leaves; the spring becomes; the gods are greatly pleased (R. Agizza, Antik Yunan'da Mitoloji, 
seems that some themes such as the disappearing of the god, his returning to the earth, winter and summer, drought and abundance, revival of the nature and the losing its liveliness was underlined especially Telipinu mythos has a different aspect from the other ones; the god got anger owing to a reason which we couldn't understand from our text, and then he disappeared (the missing god). In other myths which we mentioned above, it appears that the disappearing fact was occurred in different forms; either this god was kidnapped to the underground by the other gods (the kidnapped god), or he willingly went to the underground (the god who went to the underground). In the Hittite culture, the missing god wasn't only Telipinu. A number of gods have also the disappearing character. We can enumerate them as follows: Great Storm God, the Storm God of Kuliwišna town, the Sun Goddess, the Storm God of Queen Ašmunikal, the Storm God of Harapšili, the Storm God of Lihzina town, Anzili and Zukki, Hannahanna, the Goddess Inara ${ }^{5}$... It seems both that a mythos could be connected with different gods, and also that a mythos which belonged to same god has also different versions. The translation of the Telipinu mythos which was compiled from the different versions ${ }^{6}$ will give its interesting theme:

\section{The Translation of the $\mathrm{Myth}^{7}$}

God Telipinu is so angry and doesn't know what he does. He wears his shoes inversely. As he goes away, some troubles in the country begin.

\footnotetext{
Masallar ve Söylenceler, (Trans. Z.Zühre İlkgelen) İstanbul 2001).

${ }^{4} \mathrm{Baal}$, the fertility god, is the son of El, the main god who is the father of gods, and in the cuneiform texts, he appears as "the rider of clouds", "the thunder" and "the god of thunder", under the name of Hadad. In the Baal and Mot mythos, Baal declares to not pay tribute to Mot, the infertility and Underground god, who is the new favorite of El, his father. Thereon, Mot threats Baal by his envoys. Then Baal sends word to Mot as follows: "Not be merciless, O Mot, I am your servant, I am always a slave of your door". This words pleasure Mot and it is declared that Baal is assimilated forever. But, then, it is heard about that Baal died in Baal's field, but nobody knows the reason of his death. From the following part of the mythos, it is understood that Baal is found in the underground world, as Tammuz. Anat, sister of Baal, begins to look for him all over, and she finds him by the aid of Šapaš. And then she gets out him to Zafon Mount, she buries him and banquets for his honor. It seems that the disappearing of Baal on the earth carried over along seven years, and that the drought and scarcity prevailed during this period. After seven years, Anat seizes Mot, she cuts out him, she burns in the fire, she grinds in the quern and she sows him in the earth. The practices in question points out that various processes for cereal was symbolized (S. H. Hooke, Ortadoğu Mitolojisi (Trans. A. Şenel), Ankara 1991).

${ }_{6}^{5}$ G.Karauğuz, 2001: 38-39.

${ }^{6}$ The Telipinu mythos has three version and it consists of many copies which belonged to every version. See CTH 324; G. Karauğuz, 2001: 86.

${ }^{7}$ For the translation of this text (the first version) (CTH 324); Harry A. Hoffner, 1990: 14-17.
} 


\section{Vs. I}

5 the fog kept (filled) the windows; the smoke kept (filled) the house;

6 the woods in the oven were smothered;

7 At the altars the god were smothered, the sheep in the fold were smothered, in the stable

8 the cattle were smothered, the sheep refused her lamb,

9 the cow refused her calf.

\section{Telipinu too went away;}

11 the fertility of animals and seeds, their productivity and (also) their abundance to desert and

12 meadow he took away. Telipinu too went into the field and in the filed

13 he disappeared (mixed in). Over him, halenzu plant grew. So

14 the barley and the wheat haven't grown anymore. Cattle, sheep and human beings

15 didn't become pregnant anymore and the pregnant ones didn't give birth.

16 In order to sprout not, mountains and trees got dry.

17 In order to be hunger in the country, pastures and springs got dry.

18 The human beings and the gods are dying of hunger.

19 The Great Sun God arranged a banquet and he invited thousand gods. They ate.

20 But they weren't full up; they drank, but they didn't slake their thirst.

21 The Storm God thought about (considered) his son Telipinu: "My son, Telipinu,

22 isn't here. He went off as half cock and he took away every thing that is 
good".

23 Great gods (and) minor gods began to look for Telipinu. The Sun God

24 sent away the speedy eagle: "Go,

25 (and) seek the high mountains;

26 Look for the deep valleys, look for the blue deepness (deep and darkness seas)!"

27 The eagle went away (and) it didn't find him. But to The Sun God

28 he gave (a) report: "I didn't find noble God Telipinu."

29 The Storm God said Hannahanna (as follows): "How must we do (how must we act)!

$30 \mathrm{We}$ will starve to die. Hannahanna said to the Strom God as well (as follows):

31 "O! Storm God, go away and look for Telipinu yourself"

32 The Storm God began to seek Telipinu. To the door of the town

33 (The Storm God) came (to open), but he didn't achieve. Therefore the Storm God broke the cursor and the lock (?) of the door.

$34 \mathrm{He}$ put on and sat down. Hannahanna

35 sent away a bee : "Go! You look for Telipinu".

${ }^{8}$ The part in question follows in the second version of the mythos (KUB 33.5 II 4-19) like that: Hannahanna sent a bee. "You, go (and) look for Telipinu! When you find (him), sting his hands and feet and stand him (up). Then, take the wax and clean him completely, and purify him and bring him near me". The Storm God said to Hannahanna as follows: "The great gods and the minor gods looked for him regularly, but they didn't find him, so will this bee go and find him? Its wings are small; it is very small. However they cut in pieces". Hannahanna (also) said to the Storm God: "Stop it! It will go to (find him)". The bee departed (and) began to look for Telipinu. It looked for [ ]. It look[ed for] rivers [ ]. It looked for springs [ ]. The last part of this text is broken. This part follows in the third version of this mythos like that: "[Bee! Look f]or [Telipinu]. When you find him, [st]ing [his hands and his feet] and [stand] him [up, take wax] and [clean] his eyes and hands [completely and wip]e [him] and bring him near me". [The bee] looked for the [high] mounts; it [lo]oked for [deep valleys]; [it looked for blue deepness]; the honey [into it] was ex[hausted] [ ] was exhausted. But it [found] him [in a forest of Lihzina town], in a meadow. It stu[ng] his hands and feet. [And he (angrily) stood up]. (Then) Telipinu (said) as follows: "I was angry and I was sleeping. [Why did you wake] me [up], when I slept? Why did you speak [to me], although you were resentful? [Telipinu] got much angry. He, the spring [ ], he pulled the rivers (and) streams. 
36 The Storm God said to Hannahanna (as follows): "The great gods and the minor gods looked for him

37 and they didn't find him, so will this bee go and

38 find out him? Its wings are small, it was small too.

39 However they cut in peaces.

After a broken context, the sacrifice equipments, which were used to evoke the gods, are listed.

\section{Vs. II}

12 In this place galaktar is found.

13 (O, Telipinu, let your soul) be calm. In this place parhue [na is found.

14 (Its) essence (?) appeals to him (Telipinu).

15 In this place, ${ }^{G I S} \breve{s}$ smama is found [

16 occur. In this place, the fig tree [is found. Just as a fig

17 is sweet, so Telipinu your soul

18 should be sweet in the same way.

19 Just as an olive keeps oil in its heart, and just as a grape

20 keeps the wine in its heart, so Telipinu

21 you should ke[ep (preserve)] the kindness in your heart and in your soul in the same way.

\footnotetext{
[ ] and he mentioned about them. He overturned [ ] He overturned houses". The reason that is chosen the bee must probably relate with the honey maker characteristic of this insect. To calm god Telipinu who has already got angry and it is supposed that he will get more angry to being waked up - furthermore strung by a bee — is realized by the bee again. The bee cured the wound of god Telipinu by its honey and it also turned his painful words to the honey.
} 
22 In this place, ${ }^{G I S}$ liti is found. Telipinu, your soul

23 it anoints. Just as the malt and the beer bread combines in the soul, Telipinu,

24 let your soul combine with the words of these mortals in the same way. Just as the wheat

25 is pure, so let the soul of Telipinu be pure. Just as the honey

26 is sweet, the oil is soft, so let the soul of Telipinu

27 be sweet in the same way and be soft in the same way.

28 Look, the fine oil onto your ways, Telipinu,

29 I scattered; you, Telipinu,

30 walk in the way that was scattered fine oil; let the šahi tree and happuriyaš tree be in order (in line).

31 Just as the reed (and) the lazzai tree are in order,

32 so you, Telipinu, be in order in the same way.

33 Telipinu came back angrily. With the lightning flash

34 he roared; he struggles with the dark earth below.

35 Kamrušepa saw him and by the feather of the eagle

36 he moved off himself. He,

\section{Rs III}

1 gave over the anger; he gave over the rage, the sin

2 he gave over; he gave the resentment.

3 Kamrušepa said to the gods again (as follows): "O gods, go away!

4 Now, the God Hapantili is grazing the sheep which belong to the Sun God. 
5 and then you sorted out 12 sheep; (with the sheep) which I sorted out for Telipinu,

6 I performed (the ritual); I took a feather and "one thousand eyes" and

7 the sheep which I sorted out, I bound (prepared) for Kamrušepa 9 .

8 Above Telipinu, I fired in one side,

9 and I also fired in the other side. And then

10 I took the harm of his body, his sin

11 I took, I took his anger, his temper

12 I took, I took his negations, I took vexation,

13 Telipinu is angry. His soul and his essence

14 were hardened (as) wood. Just as the woods

15 they burned, the anger of Telipinu,

16 his temper, his sin (and) his vexation they burned in the same

way. Just as malt

17 is unusable and they don't bring it to the field

18 they don't use it as seed, they don't make bread from it,

19 and they don't give up it in the house of seal. The anger of

Telipinu, his temper,

20 his sin and vexation should also be negative in the same way.

21 Telipinu is angry. His soul and his essence

22 like a burning fire. Just as this fire is extinguished,

23 The anger (of Telipinu), his temper, his sin (and) his vexation should also extinguish in the same way.

24 Telipinu, give up your anger, give up your temper,

${ }^{9}$ For the translation of Rs. III 1-7, s. V.Haas-G.Wilhelm, 1974: 23. 
25 give up your vexation Just as the water into the drain 26 doesn't flow conversely, the anger of Telipinu, his temper and 27 his vexation also shouldn't turn back in the same way.

28 The gods are sitting under hatalkišni tree in the[ meeting place

29 under hatalkišni tree [

30 And all gods are sitting: ${ }^{\mathrm{D}} \mathrm{P}\left[\mathrm{apaya},{ }^{\mathrm{D}} \mathrm{Ištuštaya}\right.$

$31{ }^{\mathrm{D}} \mathrm{GUL}-\check{s}$ š $,{ }^{\mathrm{D}} \mathrm{MAH},{ }^{\mathrm{D}}$ Halki, ${ }^{\mathrm{D}}$ Miya[tanzipa,

$32{ }^{\mathrm{D}}$ Telipinu, ${ }^{\mathrm{D}}$ LAMA, ${ }^{\mathrm{D}}$ Hapan[tali

33 For long years, to the gods under the hatalkišni tree [

34 I have treated (well). I purify him.

\section{Rs. IV}

1 [The ox passes under you]. And you pull curl of its hair! Under you, the sheep passes under you,

2 and (as) you pull its woolen bunch, (in the same way) from Telipinu

3 pull anger, temper, sin and vexation too.

4 The Storm God comes with full of anger. The man of Storm God

5 stops him. The pot comes (boils) and wooden spoon stops him.

6 Words of the mortal also

7 should stop anger of Telipinu, his temper and his vexation in the same way.

8 Anger of Telipinu, his temper, his sin and his vexation 
9 should go away; the house should release him. The insider

10 should release him; the window should release him; the henge should [rele]ase [him], the interior

11 hall should release him, the gate of town should let him

12 The kind street should let him. To the orchard, the field, the vineyard or to the forest, he

13 shouldn't come in. He should go to the way of Sun Goddess (of the Dark Earth).

14 The door-keeper opened seven doors. He pulled seven cursors.

15 The bronze palhi vessels stand down in the dark earth. Their lids

16 (are) of lead; their handles (are) of iron. The thing which enters into their interiors

17 never goes out. He smashed into him.

18 (Therefore) the anger of Telipinu, his temper,

19 his sin and his vexation, they should catch and they shouldn't come back (here).

20 Telipinu came back to his house and understood the importance of his land.

21 The fog released the windows; the smoke released the house;

22 the altars came into congruity with the gods again; the fireplace released the log;

23 In the sheepfold he released the sheep; In the cattle barn he 24 released the cattle.Then the mother looked afterher child; the sheep took care of her lamp;

25 The cow took care of her calf; and Telipinu (took care of ) the king and the queen. 
26 and at the following days, he bestowed life, strength and long lifetime (for them).

27 Telipinu also cared about the king. Before Telipinu, 28 eya tree ${ }^{10}$ stands there; a hunting bag (from the leather) of sheep is hanging from the eya tree.

29 The fat of sheep is found in (the bag); Gì, the Crop God; and 30 (the symbols) of wine are found into it; 31 long life and descents are found into it.

32 "The soft message of lamb" is found into it; into it, 33 it obeys forever; then into it, ${ }^{\mathrm{D}}[\mathrm{xx}]$ (is) also (found) ${ }^{11}$. 34 and the right arm is found into it, and into it 35 the abundance, the fertility and the fullness is found it.

The invoking ritual, which is performed in order to turn the god back from the place where he went, is of Kizzuwatna origin and it is the product of Hurrian-Luwian common culture ${ }^{12}$. In the Telipinu mythos, it also seems clearly the traces of this cultural partnership. The Telipinu mythos is an important sample pointing out that there is a close relation between the ritual and the mythos in question.

The text consists of two parts: a) Mythos, b) Ritual

The part in which the mythos is explained was built upon the theme about the turning back of god whom disappearing unfertilized the earth. The condition which the land fell in by his disappearing is exhibited by using a number of analogies. The part, which is about the ceremonies in the ritual, also included the magical treatments, in order to turn back the god and to bring back the fertility of nature.

\footnotetext{
${ }^{10}$ H.Ertem, 1987: 110-116.

${ }^{11}$ For the translation of 27-33 lines, H.Ertem, 1987: 115.

12 As Theodor G. Gaster, 2000: 377-378, points out, "This mythos exhibits the standard phases of seasonal pattern: a) suffering, b) purifying, c) animation and d) pleasure. First phase is described with the disaster in the earth and sterility of animals; the second one with a detailed ritual which was performed in order to remove the evil into the body of god Telipinu; the third with rites in order to reanimate him; and the fourth with a narrative describing how he really calmed and how he bestowed his kindnesses to the earth".
} 


\section{The god is disappearing ...}

"Telipinu walked off to the field and disappeared in the field."

In the mythos, it is described exaggeratedly about the condition which the land fell into. Disappearing Telipinu is an agricultural god, so this event probably affects agriculture and stockbreeding at most. The suffering of agriculture and stockbreeding also influenced both human-beings directly and also gods indirectly. Then, the people get to die and there was anyone to serve the gods owing to dry the springs and pastures, or the sacrificial materials, which are offered to the gods, couldn't be supplied, due to drought. In the text, it is mentioned as follows: "The gods and people are starving to death." So, in order to seek out and to bring the Telipinu, the gods primarily got flurried: "How we should do! (Otherwise) We are going to die."

\section{The god must be found! ....}

"The great gods and the minor gods began to look for Telipinu"

The time to calm god Telipinu and to turn him back comes. The god is angry and resentful. In order to calm his anger and to remove his resentful, he must be found at first. Therefore, the place where go Telipinu went must be determined primarily. In the text, it is mentioned about this matter as follows: "Telipinu walked off to the field and he mixed (disappear) to the field".

\section{And the god is being brought back to his home....}

"Telipinu came back to his home (...) and at the following days, he bestowd (them) life, strength and long life".

The searches, which are carried out to find Telipinu, remained inconclusive, and the goddess Hannahanna has a little break to search the god in question. Then, a bee finds Telipinu, and it stings and purifies him by its wax; and it fetches him. Other gods is worried about whether a very small bee would achieve this mission, or not, but the bee goes away, and finds Telipinu, while he was sleeping in the field, and it wakes him up by stinging. Since Telipinu is waked up - also by stinging of a bee - , he gets angry thoroughly. So, "the magical practices" which was accepted as the most important method to calm the anger of god, are begun to perform. The human-being don't let themselves to the hands of the supernatural powers, and they try to prevent from the god's damages by the strength of sorcery ${ }^{13}$.

${ }^{13}$ A.Goetze, 1957: 152. 
As we observe the rituals form Kizzuwatna, it seems that the sorceries performing in those ceremonies were made into a certain plan ${ }^{14}$.

For example, in a ritual performing in order to dissolve the problems in a family - a number of problems between father and son, man and wife and also brother and sister - the persons who experienced the problems in question could be purified from anger and intolerance by various sorceries. However there was a belief about if a person could be purified by sorcery, the gods could also become clean in the same way, so the magical treatments executed for the persons were also performed for the gods. Just like the sorceries for the God Telipinu in the Telipinu Mythos.

The Sorcery Methods Which were Performed to turn Telipinu Back

\section{a) The Invoking Rituals}

The invoking rituals which came into the Hittite cultural sphere are of Kizzuwatnian origin. Owing the an ancient belief about that the gods abandoned the temples and the towns, when they got angry, these gods were invoked from where they went by "invoking rituals". It seems that a number of sacrificial material was prepared, in order to invoke the gods. The materials used in the rituals were chosen in accordance with the aim of ritual. The materials which were used in order to invoke the god Telipinu are as follows:

GIŠ $\mathrm{PÈŠ} \mathrm{"the} \mathrm{fig} \mathrm{(tree)}{ }^{15}$, GIŠ $S E_{20} E R . D U M$ "the olive tree"16, $\mathrm{GI}^{17}$, lazzai $^{18}$, galaktar "calming, sedative" ${ }^{19}$, parhuena ${ }^{20}$, GIŠsamamma ${ }^{21}$, GIŠ GEŠTIN "the grapevine, the vine" ${ }^{22}, \mathrm{DIM}_{4}$ "malt" ${ }^{\text {"2 }}$, BAPPIR "a verdure

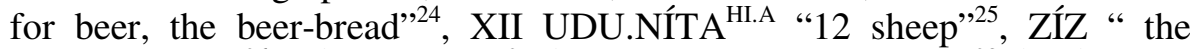
reddish wheat" ${ }^{\prime 26}$, LÀL "honey"27, İ.NUN"the melted butter" ${ }^{28}$, İ.DÙG.GA

\footnotetext{
${ }^{14}$ Büyü ritüellerinde uygulanan metotlar hakkında ayrıntılı bilgi için bk. E.Reyhan, 2003..

${ }^{15}$ HZL p.195.

${ }^{16}$ HZL p.144.

${ }^{17}$ HZL p.30 "reed".

${ }^{18}$ HW p..128 "reed”; CHD (L) (1980) s.49 “(GIŠ lazzai-, GIŠlazi-, a kind of tree or wood”.

${ }^{19} \mathrm{HW}$ p..95.

${ }^{20}$ According to H. Ertem, 1987: 25, parhuena- that is well-know its bread, must probably be a kind of cereal like wheat and barley. CHD (P) (1994), p.148-150 "parhuena-, parhuina- a kind of wheat"

${ }^{21}$ H.Ertem, 1987: 1-4, agrees with Goetze and Otten for the meaning of GIššam(m)am(m)a, as "sesame".

${ }^{22}$ HZL p.153.

${ }^{23}$ HZL p. 221 .

${ }^{24}$ HZL p. 168.

${ }^{25}$ HZL p.197.

${ }^{26}$ HZL p. 213 .
} 


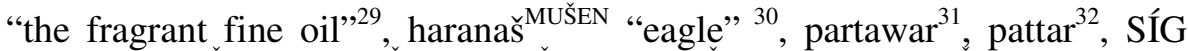

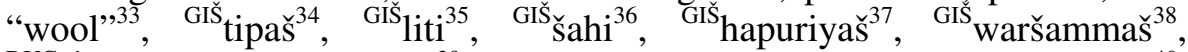
${ }^{D U G}$ ÚTUL "pot, saucepan"39, ZABAR palhi "the bronze palhi-vessel" ${ }^{40}$,

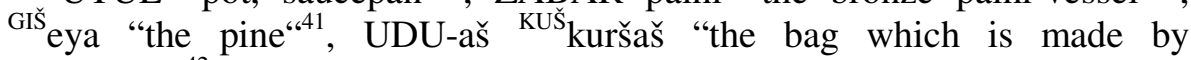
sheepskin". ${ }^{2}$

Some of these materials, especially the ones which were charming the god to turn back, were sprinkled over the ways.

"Look, I sprinkle the fragrant fine oil on the ways of Telipinu, you, Telipinu, walk over the way which was sprinkled the fine oil."

In a Luwian sorcery text, it is mentioned that a number of materials such as oil and honey were preferred, since it was believed that those materials convert bad words and curses to oil and honey, and that they make possible to run off them as oiled water ${ }^{43}$. It appears that DINGIR.MAH, Gulš and Anzili (and) Zukki, who were left their homes, since they got angry,

\footnotetext{
${ }^{27}$ HZL p. 173 .

${ }^{28}$ HZL p.107, 127.

${ }^{29}$ HZL 1989, p.259.

${ }^{30}$ HW p. 56.

${ }^{31}$ HW p.164 "wing”; CHD (P) (1994) p. 198-199 “(UZU) partawa(r) 1.wing, 2.feaather, plumage".

${ }^{32}$ HW p.166 “wing”; CHD (P) (1994) p. 240 “(UZU) pattar, ${ }^{(\mathrm{UZU})}$ pittar 1.kanat, 2.feather, plumage".

${ }^{33}$ HZL p.122.

${ }^{34} \mathrm{HW}$ p.224.

${ }^{35} \mathrm{CHD}$ (L) (1980) p. 72-73 “GIŠ leti-, liti a plant which is acquired oil; H. Ertem, 1987: 133 said as follows: "In the sorcery ceremony which was performed to come back god Telipinu, that it was chosen sweet and fatty fruits or seeds such as fig, raisin, olive and sesame, all these are about the effort intended for being disarmed and satisfying god Telipinu.

${ }^{36}$ HW p. 175 "a kind of valued wood" H. Ertem, 1987: 140, points out that this word probably corresponds to a plant that its wood was used as a firing material and which was able

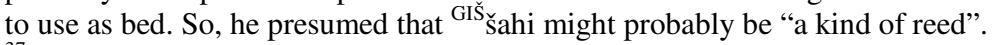

${ }^{37}$ HW p.55 "a kind of valued wood"; For H.Ertem, 1987: 121-122 it must be a plant like "reed".

${ }^{38}$ HW p.247 "straw (?), a firing material (?)"

${ }^{39}$ HZL p..270.

${ }^{40}$ ZABAR "bronze" HZL p. 250; according to Y. Çoşkun, 1979: 48, palhi "is a vessel which was made from the durable and strong materials, like iron, bronze and stone such as, and which is mentioned in the mythological text a fortiori. In his paper, Y. Çoşkun also points out the other meanings which are attributed to this vessel by scholars: "Large and big vessel, cauldron, a kind of metal vessel, barrel, cask"; CHD (P) (1994) p. 66-67 “(DUG) palhi- and (DUG) palha- are kinds of vessel which is stored liquids".

${ }^{41}$ For the eya-tree see H. Ertem, 1987: 116; S. Erkut, 2002; S.Alp, 1983: 98 ff., 100

${ }^{42}$ UDU "sheep" HZL p. 197; (KUŠ kuršaš, ${ }^{(K U S ்) ~}{ }^{2}$ uršaš "leather, skin, shield" HW p.118.

${ }^{43}$ V.Haas, 1998: 38.
} 
were pulled by aid of traces which were made of fragrant meals ${ }^{44}$. The fragrance of meals is another method to pull the gods.

The residences of disappearing gods were underground, forested areas, springs, fields, sky, sea, mountains and rivers ${ }^{45}$. As mentioned before, Telipinu walked off to the fields and disappeared there.

\section{b) To calm his anger}

By using a number of materials, it was intended not only to invite the gods to the ways, and also to calm and relieve them. The preferred materials were suitable for this aim: tranquilizer, sedative, soft, sweet and fluid such as.

These materials were used in different forms.

\section{1- The method of Analogy}

The method of Analogy was the most practiced process in sorcery rituals, and it depended upon the observations about the natural events and the well-known characteristics of products/resources. It was intended "to get the desired result by analogy". For example, in a ritual which was performed for the family quarrels by Maštigga, it was established an analogy between the impossibility of turning back of the fish to the sea again and the request about that cursed tongues, which caused to the quarrels, move away from the master of sacrifice and didn't turn back anymore.

"This fish is the bull of sea; and as this fish left from the sea, just, the cursed tongues of that day should (also) leave (from you)."

The main result which is required in the second part of an equation like "as how it did, the other should be just like that" in the sorcery of analogy in Telipinu Mythos is to take away the anger of God Telipinu, his sin and his vexation. But, during this process, it was firstly made an effort "to calm the soul of God Telipinu". To this end, a number of natural events and a lot of materials which characteristics are were known, were used in the sorcery of analogy. Some instances in the mythos are listed as follows:

"As malt is unusable and they don't bring it to the field and they don't use it as seed; they don't made bread with it; and they don't give up it in the house of seal. The anger of Telipinu, his temper, his sin and his vexation should also be negative".

"Telipinu is angry. His soul and his spirit were hardened (as) wood. As the woods they burned the anger of Telipinu, his temper, his

${ }^{44}$ V.Haas, 1998: 38-39.

${ }^{45}$ V.Haas, 1998: 39. 
$\sin$ (and) his vexation they burned in the same way".

"In this place, the fig tree is found. As the fig is sweet, so Telipinu your soul should be sweet like that".

"As the olive keeps oil in itself and the grape keeps the wine in itself, so Telipinu, you should ke[ep (preserve)] the kindness in your heart and in your soul".

"As the wheat is pure, so let the soul of Telipinu be pure".

Some analogies used in this mythos show parallelism with the ones in other rituals:

"As the water into the drain doesn't flow conversely, the anger of Telipinu, his temper and his vexation also shouldn't turn back in the same way".

The following theme also appears in the other texts.

"Then, they pour a hanneššar vessel with vine behind the rain gutter. He says as follows: "As the water pours from the roof and it doesn't come from the rain gutter again, so oath, blood, tears, sin, curse (and) being became mutilated which contaminate their evils to this house also should go away like that (and) they shouldn't come back again anymore" ${ }^{46}$.

Another analogy in the text is as follows:

As this fire is extinguished, the anger (of Telipinu), his temper, his $\sin$ (and) vexation should also extinguish in the same way.

The same motif also appears in the other texts.

"...... He sprinkles water on the fire and tells them as follows: As this burning fire is extinguished, whoever breaks this holy oath, these holy oaths should catch him, and then his liveliness, his strength, his wife and children and his prospective happiness should extinguished in the same way". ${ }^{47}$

The number of samples in the mythos points out that analogy is most practiced method.

\section{2- The method of making contact and transfer}

Another process that was used in these rituals is the method, called as making contact and transfer, based upon the principle that impurities is transferred to the materials, which was especially chosen for this special operation, by making contact between the materials in question and the

${ }^{46}$ KUB 7.41 I 28-34, V.Haas- G. Wilhelm, 1974: 27.

${ }^{47}$ KBo 6.34 IV4-11; fort he translation of this text s. A.Goetze, 1969: 353-354. 
person/god/ place that is desired to be purified. During this process, it made use of the practices which enable that impurities are taken away from the owner of sacrifice. It is also interesting that the impurities were considered as physical dirtiness in this context. The purifying method was performed by using a few of practices such as to wash with water, to apply cream, to comb or to purify by means of water and fire which were the most effective method for the owner of sacrifice in the sorcery rituals. In the rituals which were performed by Maštigga, it seems that the purifying process is performed by means of fire.

"Then, they made fires in two places and (two owners of sacrifice) (father-son, man-wife, brother-sister) pass through (the fire)."

In a ritual that was performed against an epidemic in the army by Ašhella from Hapalla town, the fire was used as an effective purifying tool. The fires were lighted and the ones who left from the sacrifice and turned back to the military camp were passed through these fire places ${ }^{48}$.

"When they left from the sacrifice and arrived (there), they poured the salt into the water and washed their hands with it. Then, they light fires in two places."

The same practice was fulfilled in order to purify God Telipinu.

"Above Telipinu, I make the fire in one side, and I also make the fire in other side. And then, I took the harm of his body, of Telipinu; I took his sin; I took his anger; I took his temper; I took his negations; I took his vexation."

In general, it is agreed that Telipinu mythos is under the influence of Hattian cultural sphere. Many materials which appear in the mythos and some Hattian terms also verify this opinion. But a number of evidence also indicates the traces of a tradition which is connected with Luwians. ${ }^{49}$ The rituals, called as "invoking gods to the ways" are of Kizzuwatnian origin; they were adopted in Hattuša later on. It seems that the Hittites were affected seriously from this rituals and this influence came out itself in the sorcery rituals. ${ }^{50}$ The sorcery methods which are mentioned above appear only in the ritual which came into the Hittite achieves as the product of Hurro-Luwian cultures.

${ }^{48}$ A.M. Dinçol, 1985: 25.

${ }^{49}$ V.Haas- G. Wilhelm, 1974: 22.

${ }^{50}$ V.Haas- G. Wilhelm, 1974: 22. 
Goddes Kamrušepa which appears especially in Luwian sorcery rituals is also mentioned in Telipinu mythos:

"Telipinu came back angrily. He roared with the lightning flash; it strikes to the dark earth below. Kamrushepa saw him and by the feather of the eagle, he moved off. He gave over the anger; he gave over the rage, he gave over the sin; he gave over the resentment" ${ }^{\prime, 5}$.

In the lines about Goddess Kamrušepa, it is mentioned that she took an eagle feather and purifies the god by the aid of this feather. The feather was frequently used as a purifying material in the Kizzuwatnian rituals. It also seems that the eagle feather can be used in different forms. For example, the feather is swung over the representative of sacrifice in Tunnawi ritual.

"Thereupon, he (Tunnawi) takes a feather and swings it over (the representative of sacrifice)" 52

The "swinging over" motif is a common practice for the Kizzuwatnian rituals. Perhuena and galaktar are distinctive materials which were used in this kind of rituals:

"In this place galaktar is found. (O, Telipinu, your soul should be calm. In this place parhue[na is found. (Its) essence (?) appeals to him (Telipinu)".

The same materials also appears in ritual of ${ }^{\mathrm{D}} \mathrm{LAMA}{ }^{\mathrm{KUŠ}} \mathrm{Kuršaš} \mathrm{again.}$

"A kureššar-fabric, the galaktar-meal and the parhuena-drinking of god ...... I tore off a pinch of wool from him (sheep)".

The motif "to hide, to lock in or to prevent to come back the objects which caused to the impurity/dirty materials", which appears in the Kizzuwatnian rituals, is also mentioned in this mythos.

"The door-keeper opened seven doors. He pulled seven cursors. The bronze palhi-vessels are found under the dark earth. Their caps (are) of lead; their handles (are) of iron. The thing which enters into their interior never goes out. He smashed into him. (Therefore) the anger of Telipinu, his temper, his sin and his vexation, they should catch and they shouldn't come back (here)".

In a ritual performed by Maštigga of Kizzuwatna, about a family quarrel, the water which was poured over the heads of two owners of sacrifice, and was used to wash their hands and eyes, was poured in a cattle horn, and the horn was sealed. So the dirty water was kept in the horn. Dirty

${ }^{51}$ For the translation of Rs.III 1-7. s. V.Haas-G.Wilhelm, 1974: 23.

${ }^{52}$ KUB 7.53 + II 4-5 V.Haas- G. Wilhelm, $1974: 24$. 
water has to be kept shut forever and never comes out again. To this end, breaking the seal of horn was remained to an impossible time.

"If ancient kings come back and check the situation of the land, this seal should be broken only at that time".

According to this belief, the anger of Telipinu, his temper, his sin and vexation were imprisoned into the palhi-vessel with iron handled and lead covered, which is found in the dark earth after it is opened seven doors and it is pulled seven cursors, and thus, it was made impossible that these evils came out again.

In this mythos, it was especially underlined a routine seasonal circle ${ }^{53}$ (the disappearing of God Telipinu = winter time; arrival of this god = summer time), and it also points out that the ritual was performed in order to prevent a possible chaos in the land, or in return for crisis which is felt in the country ${ }^{54}$. The he return of Telipinu to his home can't only be explained with a term as seasonal circle. Because, with his return, it appears that the chaotic atmosphere in the land was removed entirely in everywhere (IV 20-26). This trouble made feel itself in economical, social and religious spheres.

\section{What did happen by the departure of Telipinu?}

1-The condition of community: the fog filled the windows, the smoke kept the house; the woods in the oven were smothered into their smokes; they didn't burn anymore. The people began to starve to death. The people couldn't give birth.

2- The condition of agriculture and breeding: The fertility, productivity, growing and abundance of animals were lost. The barley and the wheat didn't grow. The cattle and the sheep couldn't give birth.

3- The condition of gods: gods in the altar choked; they began to starve to death.

These negations were removed by the arrival of God Telipinu. What did happen by the return of Telipinu to the land?

1- The condition of community: the fog released the windows; the smoke released the house; the fireplace released the log; the mother took care of her child,

2- The condition of agriculture and breeding: The sheep took care of her lamb,

${ }^{53}$ T.Ökse, 2006: 67-71.

${ }^{54}$ T.R.Bryce, 2003: 333. 
3- The condition of gods: The altar came into congruity with the gods again.

Gods come together in order to indicate that they are pleased to return of God Telipinu, and perhaps to persuade him to not leave his land anymore. God Telipinu also sits among these gods.

"The gods sit down in the meeting place, under the hatalkišni-tree; under the hatalkišni-tree all gods are sitting down: ${ }^{\mathrm{D}}$ Papaya, ${ }^{\mathrm{D}} \mathrm{I}$ štuštaya, ${ }^{\mathrm{D}}$ GUL-šeš, ${ }^{\mathrm{D}} \mathrm{MAH},{ }^{\mathrm{D}} \mathrm{Halki},{ }^{\mathrm{D}}$ Miyatanzipa, ${ }^{\mathrm{D}}$ Telipinu, ${ }^{\mathrm{D}}$ LAMA, ${ }^{\mathrm{D}}$ Hapantali.

So, the land retrieved to its prosperity again. This case is symbolized with "life, strength and long life" which were provided to the King and the Queen. eya-tree which is able to remain green in every season and a number of concepts as "long life and generations" and "abundance, fertility and fullness" into the bag that is hang over this tree, are indicators which point out to being reached to the desired aim and that the land is saved from its bad condition.

In a passage of Hittite Laws codex which is about the tax duty, the lines related with eya-tree illuminates the special position of this tree:

“..... the man who reigns in Nerik Town, in A[rina] town and in Zippalanda town, the reverend in every land, their house < should be exempt $>$ and their "participator" should execute their huzzi-duties. In Arinna town, the man who is able to be seen an eya-tree in hi[s house]-door when the eleventh month comes in Arinna also should be exempt from his tax duty"

From this passage, it also seems that the reverends, except the administrators of some sacred towns such as Arinna, Nerik and Zippalanda and the "participators" who undertook the luzzi ${ }^{56}$-duty, were exempt from the tax duties. It is also mentioned that the one who is seen an eya-tree in his house door, when the eleventh month came in Arinna town, was exempt from the entire taxes. It can be interpreted this case as the reduction in the taxes by increasing of the prosperity in land ${ }^{57}$. In Telipinu mythos, it may also be used this theme as the indication of increasing of prosperity in the land.

\footnotetext{
${ }^{55}$ F.Imparati, 1992: 69,71.

${ }^{56}$ E Reyhan, 1998: 482 "There are two terms which frequently appear in the Hittite texts: šahhan and luzzi; šahhan is a kind of tax which is given to state in return for the field that is under private property (the tax which is paid for Public service). Luzzi is interpreted as "slavery" and "working duty" such as the restoration of official buildings and temples, and also renovation of military institutions and streets".

${ }^{57}$ F. Imparati, 1992: 220-222.
} 


\section{Conclusion}

In the societies whose economies depended upon agriculture and breeding, it seems that the agriculture god had important functions. Regular rains, fertility of earth, good kind of seeds and fruitfulness of product were in this god's power. So, if a god, who is responsible from all those, abandons (disappear) his country, he has to be found without loss of time. That all gods were required to be mobilized in order to find the disappearing god was a necessity for themselves, and it would also save the people from difficult condition which they fell into. However, insufficiency of products means that the people would starve to death. The death of peoples naturally would affect the gods at most; any person would remain to serve them, and the materials which are offered to the gods wouldn't be found anymore. Being seeking out Telipinu and Telipinu's return to his home with his fertility was a necessity for both the prosperity of a land and of people living there and also of the royal family (king and queen) and of the entire gods.

In the myths about disappearing god which are belonged to Hittites, there are a number of traces about the relationship between disappearing (kidnapping) of god and dearth/scarcity/ infertility, i.e. being seeking out gods and improving the negations can be observed clearly. With the return of Telipinu, the agriculture god, the negative events, which his disappearing caused to, removed entirely. Furthermore, in the mythos, some indications points out that it was saved from a troubled case in the land, which isn't only able to be explained by the changing of seasons. The terms "life, strength, long life" which was bestowed to the king and the queen, eya-tree which is able to remain green in every season and the bag hanging on the eya-tree that included "long years and generations" and "abundance, fertility, fullness" must probably be perceived as the signs pointing out that the negative situation in the land came to an end.

\section{Bibliyografya ve Kısaltmalar}

Agizza, R. (2001) Antik Yunan'da Mitoloji, Masallar ve Söylenceler, (Trans. Z.Zühre İlkgelen) İstanbul.

Alp, S. (1983) Beitrage zur Erforschung des hethitischen Tempels, Kultanlagen im Lichte der Keilschriftexte, Ankara

Armstrong, K. (2006) Mitlerin Kısa Tarihi (Trans. D.Şendil), İstanbul.

Bryce, T. (2003) Hitit Dünyasinda Yaşam ve Toplum, Ankara.

Coşkun, Y. (1979) Boğazköy Metinlerinde Geçen Bazı Seçme Kap İsimleri, Ankara.

CHD; The Hittite Dictionary of the Oriental Institute of the University of Chicago, Chicago 1980 vdd.

CTH; E.Laroche, Catalogue des Textes Hittites, Paris 1971. 
Dinçol, A.M. (1982) Anadolu Uygarlıkları I, Ankara.

(1985) "Ašnella Rituali (CTH 394) ve Hititlerde Salgın Hastalıklara

Karşı Yapılan Majik İşlemlere Toplu Bir Bakış”, Belleten Cilt:XLIX Sayı:193, Ankara.

Eliade, M. (1993) Mitlerin Özellikleri (Trans. S.Rifat), İstanbul.

Erkut, S. (2002) "Hititçe GIŠ eya- ve Onun Türkçe Karşılığı Hakkında", 14. Uluslararası Türk Tarih Kongresi, Ankara. 2002.

Ertem, H. (1987) Boğazköy Metinlerine Göre Hititler Devri Anadolu'sunun Florası (2.Bask1), Ankara.

Gaster, Theodor H. (2000) Thespis, Eski Yakındoğu'da Ritüel, Mit ve Drama, (Trans.Mehmet Doğan), İstanbul.

Goetze, A. (1957) Kleinasien2, Zweite neubearbeitete Aufl. (Hand-buch der

Altertumswissenschaft), München.

(1969) "Hittite Rituals, Incantations and Description of Festivals",

Ancient Near Eastern Texts Relating to the Old Testament, Princeton.

Haas, V. - Wilhelm, G. (1974) "Hurritische und Luwische Riten aus Kizzuwatna, Hurritologische Studien I", Alter Orient und Altes Testament Sonderreihe III, Kevelaer und Neukirchen-Vluyn.

Haas, V. (1998) "Die hurritischen Ritualtermini in hethitschem Kontext", Corpus der hurritischen Sprachdenkmäler (ChS 9), Roma.

Hoffner, H.A. (1990) Hittite Myths, Atlanta, Georgia.

Hooke, S.H. (1991) Ortadoğu Mitolojisi (Trans.A. Şenel), Ankara.

HW; Friedrich, J. (1952) Hethitisches Wörterbuch, Leiden.

HZL; C.Rüster- E.Neu (1989) Hethitischen Zeichenlexion, Wiesbaden.

Imparati, F. (1992) Hitit Yasalarl, Ankara.

Karauğuz, G. (2001) Hitit Mitolojisi, Konya.

Ökse, A.T. (2006) "Eski Önasya'dan Günümüze Bahar Bayramları ve Bereket Törenleri”, Türk Arkeoloji ve Etnografya Dergisi, Ankara.

Reyhan, E. (1998) "Hititlerde Toprak Tahsisi", III.Uluslararası Hititoloji Kongresi Bildirileri (Çorum 16-22 Eylül 1996), Ankara.

(2003); "Hitit Büyü Ritüellerinin Uygulama Şekilleri Üzerine Bir İnceleme", Archivum Anatolicum Cilt:VI Sayı:2, Ankara 2003. 